\title{
Africa, Poverty and Forces of Change: A Holistic Approach to Perceiving and Addressing Poverty in Africa
}

\section{Tayo Raymond Ezekiel Eegunlusi}

General Studies Department, School of Sciences, Federal University of Technology, Akure, Nigeria

Email: kingadetayo@yahoo.com

How to cite this paper: Eegunlusi, T. R. E. (2016). Africa, Poverty and Forces of Change: A Holistic Approach to Perceiving and Addressing Poverty in Africa. Open Journal of Philosophy, 6, 368-391.

http://dx.doi.org/10.4236/ojpp.2016.64035

Received: September 12, 2016

Accepted: October 30, 2016

Published: November 2, 2016

Copyright $\odot 2016$ by author and Scientific Research Publishing Inc. This work is licensed under the Creative Commons Attribution International License (CC BY 4.0).

http://creativecommons.org/licenses/by/4.0/

\section{(c) (i) Open Access}

\begin{abstract}
This work argues that Africa's condition of poverty lingers because the continent fails to view poverty in its holistic sense in her attempts at tackling her economic challenges. Other types of poverty exist, such as mental poverty, moral poverty, emotional poverty, spiritual poverty, political poverty and social poverty, which pose great problems for the continent. Obviously, her failure to give worthwhile attention to solving these problems largely contribute to why she has not really benefited from her vast wealth of human and material resources. Also, this lack of holistic approach to perceiving poverty often allows Africa to be swayed by global forces of change such as socio-cultural factors, political factors, wars and terrorist activities, technological forces as information technology and electronic media, and so on. Consequently, majority of Africans seem to be blinded to the reality of possibility of redemption from the continents precarious economic condition. Thus, neglecting their nations, they emigrate abroad, under the guise of seeking enabling environment for productivity and survival. At the same time, those at the helms of affairs perpetuate the economic poverty status-quo by greedily enriching themselves. Thus, the continent becomes an unfortunate victim of parochial perspectives as other continents become undeserving beneficiaries of her endowments and heritages. Using philosophy's critical and argumentative methods of empirical, conceptual and historical analysis, this paper debates that a holistic perspective to poverty can help control global forces of change in ways that will favour Africa's total development and enhance her profiting in the globalisation era.
\end{abstract}

\section{Keywords}

Conflict of Interests, Development, Forces of Change, Holistic Approach, Poverty, Resources 


\section{Introduction}

It is common among African scholars and people to identify some problems of underdevelopment in Africa and adduce reasons for why she is behind in global development. Presently, the question of development is topmost in the minds of Africans. As such, philosophical discourses on African development have shown conflicts of views by philosophers across different epochs, including the modern and postmodern eras (Abraham, 1962: p. 38; Hensbroek, 1998: pp. 7-202; Coetzee \& Roux, 1998a: pp. 1-148; Coetzee \& Roux, 1998b: pp. 1-168; Momoh, 1981: pp. 8-22; Oguejiofor, 2002: p. 117; Appiah, 1992: pp. 3-17; Appiah, 2003: pp. 339-340). On one hand is the wide literature including those of writers like David Hume (Hume, 1826: p. 12; Enyimba, 2005: pp. 5-6), Immanuel Kant (Kant, 1997: pp. 38-48; Eze, 1997: pp. 115-122), G. W. F. Hegel (1956: p. 93, 99), John Locke (Dixon, 2010; Richardson, 2011: pp. 107-112) and many others who viewed Africans as backward and mentally inferior (Appiah, 2005: p. 26). On the other hand are the ideas of contemporary African writers such as Bodunrin (1981: pp. 161-179), Hountondji (1983: p. 43), Kagame (Kagabo, 2004: pp. 231-241), Oruka (1990: pp. 45-46), Mbiti (1969: pp. 1-50), Wiredu (1998) and others that gingered a host of later writers to focus more on African development (Gyekye, 1997: pp. 192-203). What actually provoked the second group was the fact that the abuses of the African mentality by the first group was compounded by the works of writers as Placid Pempels, Lucien Levy Bruhl and later African writers such as Leopold Sedar Senghor whose analyses demean the African's intelligence (Mudimbe, 1986: pp. 89-114). Particularly, Bruhl and Sengor thought that Africans were basically passion-driven than reason-driven (Irele, 1986: p. 127, 155). Unfortunately, wholesale imbibing of this reasoning affected (and still affects) many Africans who acted without questioning the ideas they received from these further abusers of the African mind. As such, their potentials were undermined as they considered themselves inferior. This had an impact on the continent's development.

In reaction to people like Tempels, Bruhl and Sengour, many contemporary African writers developed schemes of ideas to emphasise the place of the reasoning power of the African in human daily affairs in their discourses on the question of what qualifies as an African philosophy. Though later writers commended them for their attempts, they still felt sympathy for them for sheer waste of precious time on such a question rather than focusing on the question of African development (Irele, 1993: pp. 6-8; Mudimbe, 1998: pp. 51-54; Himmelstrand, 1994: pp. 16-35; Adesina, 1994: pp. 183-188). These new crops of writers saw no reason why concerns for what African philosophy is should be elevated above the issues of development. Quoting Marx's famous expression that the "philosophers have only interpreted the world in various ways; the point, however, is to change it" (Marx, 1956: p. 69), they thought that African scholars' most important focus should be identifying and addressing developmental problems. This paper shares these thinkers' view that the discourse of African development should be taken more seriously.

Obviously, improper identification of obstacles to African growth makes us to often 
blame people and our past while we fail to look inwards to identify common pitfalls that cause national setbacks and promote poverty among a people. For decades, discourses on development have seen Africans of revolutionary frame of mind quoting twentieth century writers as Walter Rodney (1972: pp. 103-222) and Frantz Fanon (1967: pp. 1-191; 1983: pp. 1-118) to justify why and how Africa became underdeveloped. Even though elements of truth exist in the ideas of Rodney, Fanon and others about how Europe underdeveloped Africa or how colonialism undermined Africans' potentials at personal and national levels of development, current events reveal that Africans continue to underdeveloped themselves, based on their choices and certain deluded perspectives, despite their continent's vast human and material potentials. Africans have allowed their continent to be controlled by certain forces of change but largely to their detriment. We have however failed to answer perennial questions such as: Why is Africa being continually used and dumped by outsiders and her own people? What factors really undermine Africa's growth? How should the challenges of African development really be tacked?

It is sad to affirm that, up till now, Africa has been unable to develop as she should because she has not tackled her problems by adopting a holistic perspective to growth and growth sustenance. For long, we have focused on economic poverty and neglected all other types of poverty, which ought to have been addressed. It, thus, becomes easy for African nations to be swayed and deluded by a monolithic conception of poverty that eliminates proper appraisal of the African poverty situation. If other types of poverty are addressed, economic poverty will be overcome and the nations can gain material relevance and human welfare will be enhanced. Consequently, because of their importance in overcoming economic poverty and how their neglect contributes to negatively impacting mankind, we shall discuss these other dimensions to poverty in tandem with economic poverty or material poverty while our major focus shall still be towards how to overcome economic poverty. On the overall, in this work, we cannot undermine an eclectic interrogation of the poverty situation, which will enhance its proper understanding and consequent finding of lasting solutions to the present poverty crisis in Africa. Thus, this paper is an attempt to address the problems leading to underdevelopment in Africa and how the continent can successfully control global forces of change to enhance her growth. Arguing in favour of a holistic approach to an examination of the poverty situation in the continent, in pursuing its objectives, the paper adopts conceptual, historical and empirical analysis to shed light on the various aspects of poverty in Africa.

\section{The Idea of Poverty}

Poverty in its simplest sense is a state of lack of something which one really needs. In this instance, one may despair and be heartbroken for not possessing what one needs. Generally, the term "poverty" is usually used as a reference word for the inability to satisfy human physical or materials needs. By this, an individual, a nation or an entire continent may be regarded as poor because of lack of material wherewithal to cater for 
their needs. In this regard, those who own material resources are regarded as rich while those who do not are said to be poor. Hence, rich-poor dichotomy exists in the world (Pogge, 2007: pp. 2-53). Over centuries, scholars have alluded to this kind of human poverty. Depicting the condition, Halvorson (2003) said:

Ahead of any lofty social ideal or political ideology, the depth of human deprivation demands our attention. The ongoing tragedy of large numbers of human beings living in absolute poverty, malnourishment and famine is incomprehensible. Even considering the situation at length - so long as it appears intractable-is likely to leave one's conscience, weary from overexposure to human suffering, in a state of compassion fatigue.

Also, in attempting to capture what poverty is, Mariano Rojas affirms that poverty is that which is measurable by satisfaction of human welfare. In this wise, it will be "reasonable to accept that a poor person is one whose well-being is low; thus, poverty depends on the specific concept of human well-being" (Rojas, 2014). By this, he advocates the necessity of studying human welfare to be able to assess poverty and formulate policies for its reduction. He makes a distinction between a conventional definition of human welfare and a subjective one. The conventional definition is known by certain indices such as 'income, consumption, socioeconomic situation and access to public services" (Rojas, 2014). On the other hand, subjective poverty is that which bases on an individual's attribution of poverty status to himself. Of note here is the fact that Halvarson's and Roja's ideas of poverty are limited descriptions of poverty.

In attempting to categorise poverty, Thomas (2001: pp. 561-563) highlighted two perspectives to poverty: the "orthodox" and "alternative" views. Orthodox poverty reveals human incapability to eat or eat well and make necessary provisions for ones "basic material needs." The purpose of the orthodox way of seeing poverty is to allow an economy to graduate from a predominantly agrarian stage to an industrial one propelled by agendas for productivity. As such, it relies on strategies for investments, expertise and the know-how about how industries carry out their activities. It also presupposes that chances are of gaining from an open market economic system the results of which can be determined by the records of a nation's Gross Domestic Product. On the other hand, the alternative idea of poverty deals with people's deficiencies at meeting their material and non-material needs by their efforts. Its focus is on the need to ensure that human welfare is adequately taken care of by the society as far as the socio-economic and political considerations are concerned. It also emphasises a "bottom-up approach" to doing things that pride in indigenous knowledge and skills, the involvement of low-salaried people in petty businesses, environmental sustenance and satisfaction of welfare. The yardstick for measuring it is human (material and non-material) satisfaction, political strength and an assessment of the status of the human environment.

In dealing with Thomas' idea above, the distinction between the orthodox conception of poverty and the material aspect of alternative view of poverty does not seem necessary as both can still be accommodated under material poverty. It would probably 
have been more tolerable to consider or treat both as basic and secondary aspects of poverty. However, her conceiving of the non-material aspect of poverty is laudable. It affirms our stand that poverty is not only material. On the overall, if all the above views are taken together, what counts as a comprehensive description of poverty includes whatever a person is supposed to have or manifest that he lacks ability for. It is a situation of material and non-material deprivation that puts man in a state of despair or frustration. Taking this to consideration, issues involved in poverty may be from physical to spiritual needs, such as human inadequacies, material insufficiency, intellectual weakness, and so on. For long, the world's way of describing poverty only in economic terms has obfuscated our thoughts or hampered our initiatives. We shall begin our exploration of the different conceptions of poverty by addressing poverty from this economic viewpoint, in our attempt at clarifying and dealing with the issues involved in the idea of poverty as far as Africans are concerned.

\subsection{Economic Poverty}

Economic poverty is lack of material and financial resources to meet human needs. It is the aspect many usually perceive as threatening human welfare. This is basically because human survival depends directly on material possessions. In attempting to address global economic poverty and the need for international assistance to the materially poor nations by the rich, Peter Singer (2002: pp. 150-170) sufficiently criticised the rich nations for neglecting the needy peoples of the world. He discussed the critical state of the world's poorest countries and their untold sufferings, saying:

According to the UNICEF report, released to the media on September 13, 2001, more than 10 million children under the age of five die each year from preventable causes such as malnutrition, unsafe water, and the lack of even the most basic health care. Since September 11, 2001 was probably just another day for most of the world's desperately poor people, we can expect that close to 30,000 children under five died from these causes on that day-about ten times the number of victims of the terrorist attacks.

The above quotation shows indices of economic poverty in the world. Economic poverty is one of the menaces the world currently faces and has faced for centuries. While people like Singer and Rawls hold positions that are sympathetic and empathetic to the plight of the world's poor, and want the world to exercise or perform a duty of assistance (Rawls, 1999: pp. 30-32; Singer, 1986: pp. 573-580) to them, others like Nozick (1974: pp. 156-164) never think it necessary to allow some people, through state patterned redistribution based on coercion in forms of taxes and other means, to reap from other people's resources that they justly acquire so as not to violate their rights to keep what they justly own. Obviously, economic poverty is caused by a number of factors such as poor planning for the future, bad discernment in investments, wars, natural disasters, man-made environmental problems, human indecency, poor information, and a host of other factors. These constitute nightmarish factors for the inhabitants of 
the world, most especially in the severely less-advantaged nations. In certain cases, one may possibly be unable to do anything about natural disasters but we can certainly do something about a host of other causes of economic poverty. In Africa for instance, we have been able to make and keep ourselves materially poor because we have done nothing about these causes. Why has economic poverty lasted in Africa? Why are African nations easily swayed by global forces of change in the direction of economic unprofitability and national instability? We hence turn to what we consider to be the other types of poverty that have kept us where we are. We will begin with the analysis of these factors, then discuss forces of change before we examine the consequences of the types of poverty on Africa. We will then end with our suggestions on the way out of the present African predicament of material poverty.

\subsection{Mental/Psychological Poverty}

There is mental or intellectual poverty, the poverty of the mind. It has degrees. First, it is the inability to engage the mind in intellectually productive means and achieve good results that facilitate personal or national development. This may be the inability to act intelligently as becomes necessary. Second, it has much to do with deficiency in knowledge acquisition, appropriation and exhibition such that one is not abreast of certain important facts necessary for knowledge-enriching enterprises. It is to be oblivious of certain useful guides to attaining worthwhile productive uses of knowledge (Velasquez, 1999: pp. 7-9, pp. 360-366). This may derive from laziness in taking in or appropriating information. It is one of the common ways by which the developing nations further keep themselves in underdevelopment. Third, it is a mental deficiency due to inability to cope with diverse systems of learning or highly theoretical issues. For instance, there are people who prefer bowling and other practical feats to the rigorous academic disciplines and derive pleasure from such while despising theoretical consideration of issues. Usually, this stems from a lack of interest or inability to handle knowledge related issues (Russell, 1945: p. 61, 92). However, there are gifted people who never maximised their potentials and, thus, technically disable themselves by an inactivity coupled with lack of drive for mental development. As such, these never profit from the knowledge enterprise.

\subsection{Moral Poverty}

Another type of poverty that can accompany mental poverty is moral poverty (Beitz, 2005: p. 12; Wight, 1966: p. 20). To be morally poor is to lack a good sense of moral judgments that can promote healthy personal and societal moral values. Moral poverty is, simply, the failure of the human character. It is the result of the depravity of the human mind. It is a situation of the violation of the moral principles, whether consciously or unconsciously. Moral poverty sometime comes to the fore when conventional realities and moral values that have kept our societies to be morally relevant, promoting human worth and viable societal human relations, are challenged. At such occasions, caution is thrown to the wind while we lose grips on such conventional realities. Thus, 
as we try to create new systems of values, justifying human moral failures, we take for granted that human nature has, essentially, been the same across history and cannot be changed. To illustrate this fact, let us read this popular Yoruba elementary school poem:

Eéfín nìwà, rírú ló ń rú —character is a like a smoke and will always ooze out;

Ènìyàn gbokèèrè níyì _ - people are prestigious when perceived afar off;

Sún móni là á mòse eni _ closeness makes us see how a man behaves;

İwà kìi foníwà sílè — -character never deserts its owner;

İwà omo ló ń somo lórúko —a child's behavior christens him;

Ará dára ó ku ì̀à - - the body is good but for character;

Óri dára ó ku ide - the head is good but for crown;

Esè dára ó ku bàtà _ - the feet is good but for shoes;

B’énìyàn dára tí kò n'iwà -if a man is beautiful without character;

Ó pàdánù ohun ribi ribi - $\quad$ he has lost something great;

İwà lewà omo ènìyàn — _character makes a man beautiful.

Two things are noticeable from the above recitation. First, it directs attention to the fact that human character, generically, is not changeable. Observations bring us to the realisation of the fact that man is capable of good and bad characters. Such, character traits have been conceptualised based on observations of what they look like across several centuries. Second, the poem equally shows that moral poverty lingers when human nature is not subject to modulation or modification by subjection to the dictates of moral values. We sometimes do not realise that we cannot change human nature. For instance, negative emotions as anger, malice, strife, envy, and seditious practices remain part of man's nature or negative character traits. Also, poverty-imposing conducts as laziness, gambling and wasteful spending, say through visiting brothels to spend one's hard-earned income on gratifying sexual desires, depict faulty character. However, these unenviable traits can be curtailed or tamed by constantly learning and imbibing of moral values (Aristotle, 2004: p. 23) and by purposeful living. This is why giving adequate attention to expressions like self-control, temperance, and so on, show that we can embrace moral values useful for us and societal development as means of being in right moral standing. In certain cases, moral poverty derives from emotional poverty.

\subsection{Emotional Poverty}

Basically, emotional poverty is psychological in nature. Related to the issues raised in the last paragraph, emotional and moral types of poverty can assume metaphysical status. This is the sense in which the metaphysical ideas of freewill and determinism underpin discussions on morality and emotional dictates. This is not our concern here. Succinctly put, emotional poverty is the human deficiency to control one's emotion. It sometimes admits of an exuberant and edgy emotional display devoid of meaningful rational reflection, which may debar a person from self-realisation or productivity. It may later lead to long or short term depression and long period of emotional trauma 
that paralyses a person's activities when he later gives thought to the insensibility of his actions. By this, emotional poverty has high tendencies or possibility of leading to psychological disorders. The flaws and the consequences of subjection to negative emotions are part of the basic things Aristotle strove to combat with his doctrine of the mean by recommending a middle ground between the extremes in our objects of pleasure. Negatively yielding to the pleasures or emotional dictates corrupts moral virtue. There are things that count as immorality or objects of moral depravity, which show an extent of moral poverty and bring shame to those involved in them. For these, Aristotle (2004: p. 31) said,

... not every action or feeling admits of a mean. For some have names immediately connected with depravity, such as spite, shamelessness, envy, and, among actions, adultery, theft, homicide... It would be equally wrong, therefore, to expect there to be a mean, an excess and a deficiency in committing injustice, being a coward, and being intemperate, since then there would be a mean of excess and a mean of deficiency, an excess of excess and a deficiency of deficiency.

To become morally virtuous and not become immoral, one has to make "rational choices" despite emotional dictates. This is because virtue "is a state involving rational choice, consisting in a mean relative to us" (Aristotle, 2004: p. 31). This shows that failure to think about moral principles and make right moral choices could lead to perpetuating moral poverty. Moral poverty could also be pronounced if there is spiritual poverty.

\subsection{Spiritual Poverty}

While not hinging our view on the body-soul or mind-brain duality arguments, by spiritual poverty we mean a situation of lack of purity or sanctity or sanity of the human soul. It derives from man's inability to recognise his spiritual importance. Consequent on this weakness of spiritual relevance, human lives allow moral defilements in their various forms to thrive. When the soul is impure moral depravity is enhanced and humans promote all sorts of indecencies. When the soul is pure, the human conscience is positively affected and it guides moral behavior in ways that promote fellow feeling. Also, man is able to reflect on life's important questions with clear mind. Osigwe Anyiam Osigwe's views lend credence to this.

According to Osigwe, man is made up of spiritual and physical elements. At the same time, he has essential qualities that should make him desire to be in tandem with God, a spiritual entity. He strives for self-mastery and an awareness of himself. This self-mastery, to man, is most primary foundation for his existence which helps him to ask certain vital questions necessary for human existence and moral virtuousness: Who am I? From whence am I? What am I here for? Whither goal from? What is my place in the cosmic eternal scheme of things? What is life? What is death? (Oladipo, 2009: pp. 28-31) Asking these questions helps man to embark on a soul-searching endeavour to purify himself through a thinking process to overcome obstacles to human fulfillment 
and depose corruption. By this, he can live a meaningful life through reordering his values. In giving considerations to these questions, human innate moral goodness comes to the fore and man is able to develop, and remove all possibilities of corrupt practices and ensure justice in the society by promoting what is true.

To Osigwe, this idea of truth is at the centre stage in human awareness of the laws directing things in the world and the existence of beings that are divine (Anyiam-Osigwe, 2004: p. 33). By coming to terms with an understanding of the truth based on self-awareness, we can transform our lives and our societies (Oladipo, 2009: pp. 29-30). Though we may not agree with Osigwe on every point of his philosophy, there is much moral poverty in our world because we refuse to do the spiritual exercise of soul-searching and ponder on the truth and reality of our own existence. Thus, spiritual poverty leads to the perpetration of moral poverty. Where all the above types of poverty thrive, social poverty is imminent.

\subsection{Social Poverty}

Social poverty is the poverty resulting from deficiencies in human interaction. This is the underlying factor in criminal activities and wars. It bases on human ill-will or nonchalance in relating well with others such that mutual survival, mutual help, mutual benefits and mutual development are hampered. Obviously, good social relations should guarantee bilateral or multilateral benefits. In human relations, there are behavioural traits that are spoilers of social relations (de Soysa, 2001: pp. 6-7). These may hinder or totally eliminate all possibilities of benefiting from social interactions, and are not difficult to identify. They include things as hatred, variance, indecent acts capable of provoking others, enmity, strife, ill-temper and ill-will in relating with people, causing dissensions, entertaining party or factional spirit, etc. On a number of occasions, individuals and nations give the impression of being diplomatic but exhibit some of these traits as they relate with themselves. It could then be obvious that what is called diplomatic language is sometimes a coded or hidden lie that only allows for an individual or a nation to satisfy the urge for personal benefit without adequate consideration of the others' interests. On a number of occasions, this manifests in relation to global forces of change that derive from human activities as against the natural ones.

\section{Consequences of Poverty on Africa}

The above types of poverty, at different times, produce consequences that are deleterious to African people. Putting these into thought, on the overall, in the modern world, poverty appears to be harsher on Africa than any region of the world. As considered by Nicholas Minot, Mohamed Abdelbasset Chemingui, Marcelle Thomas, Reno Dew and David Orden, in their analysis of four African countries (Egypt, Tunisia, Syria and Morocco), Africa's poverty situation is high (Minot, 2010: pp. 67-200). This extensive poverty manifests in a number of ways. First is that it results in malnourishment, starvation, sicknesses and diseases (UNEP, 1992: pp. 1-50; The World Bank, 1990: pp. 24-39). On a number of occasions, these also lead to high mortality rates among peo- 
ples in the region. Thus, statistically, human life-expectancy shortens. Second, poverty creates inequalities between different communities and peoples in the same areas within Africa . For instance, some parts of Africa are poor and are far behind others in development. A result of this is that Africa's dependency ratio is very high compared with other races of the world. Considering this, poverty has made the world to be viewed in North-South divide in global political arena (Dower, 1998: p. 109). This divide talks of the distinction between the influential, rich and developed nations (the North) and the struggling, poor and developing nations (the South) which incorporate most African nations. Obviously, this divide shows the wealth disparity and poverty levels of the two groups. While the North is known to be essentially wealthy and has well developed industries, the South struggles to develop and wallows in abject poverty.

Third, the condition of poverty in Africa makes it open its doors to undue exploitation through the antics of the rich nations. This exploitation manifests in two ways: i) through the activities of the transnational corporations (TNCs) that operate in the developing countries but exist to favour the interests of their home countries rather than their host countries and ii) through the activities of the multilateral organisations (MLOs), especially the International Monetary Fund, World Bank and the World Trade Organisations (Stiglitz \& Charlton, 2005: pp. 79-80; Stiglitz, 2007: p. 9, Stiglitz, 1996: pp. 151-175). By the MLOs' giving of stringent conditions to the struggling nations that are making efforts to get out of poverty, the economies of many of these nations have been destabilised. This is because the conditions and the economic restructuring strategies these MLOs suggest to the nations that should take a long time to implement are forced on the developing nations to be implemented within a relatively short period (Stiglitz, 2002: pp. 99-105). This made the national economies turn out worse. As at now, after borrowing from the IMF and World Bank and other lending agencies to finance their economic budgets, what is supposed to be freedom has become another burden that further deepen the level of poverty among the people. This is moreso because freedom from debt eludes the people and their nations' debt levels increase and the debt crises escalate. Considering these, it is unfortunate, that the worst outcome is that poverty lingers on the continent and the masses of the people are the ones at its receiving end. Thus, the condition of poverty in Africa makes the ordinary people to suffer while it drives those who have control of power in these nations towards seeking personal fulfillment in looting of national treasury as they consider the chances of keeping the ill-gotten wealth for the future. Through this way, much wealth stashed away in foreign countries has not been retrieved. Unfortunately, the leadership greed intended as means of preserving family lineages and securing the future has deprived many nations of the privilege of utilising their resources for meaningful national exploits to gain good national results.

Fourth, in reactions to the above, there have been multidimensional conflicts in different nations. In certain cases, there are conflicts over how to share the little resources available (Omeje, 2006: pp. 477-478; Watts, 2004: pp. 1-19). This used to end in a scamping that intensify brigandage in many local communities as many of those who feel 
cheated trouble those they perceive as being apathetic to their plight as the poor and denying them what they need (Saliu, Luqman, \& Arazeem, 2007: pp. 275-293). Also, heightening are situations in which the innocent suffers unjustly and their lives are threatened by the activities of the brigands. Besides these, conflicts of morality come to the fore as people set different standards of morality based on their personal or group deficiencies. For instance, those who have become rich by looting national treasury usually perceive looting in this respect as good since they have opportunities to satisfy their urges and enjoy what is not legally theirs. At the same time, many who lack the means of control to steal from national coffer desire to steal and enjoy what they steal. These disdainful interpretations of morality, which question the veracity of our claims to be possessing moral worth, ridicule Africa before other nations and make the continent to be classed as undignified (Ó’Tuathai, Herod, \& Roberts, 1998: pp. 610-640). Thus, the disdainful moral standard becomes exalted and conflict with the moral views of those who are ready to do what is right and based on moral values as truthfulness and integrity.

In attempts to find solutions to their problems of poverty, people usually move to regions where they hope to have means of livelihood. Thus, resulting is rural-urban migration. Rural-urban migration destroys the economy of the poor regions, as people desert the rural economies, and at the same time, it occasions urbanisation of poverty in the new areas people migrate to as there are stiffer competitions for the opportunities available (Bigman, 2011: pp. 154-159). By the above, many nations have not really been able to witness growth in their Gross Domestic Product and Gross National Product while the ones that grow have their resources squandered by leaders who consider it natural to gain at the expense of their people. Thus, the escalating poverty makes mockery of human value and moral worth is heavily devalued. As we examine how to tackle poverty holistically in Africa, let us quickly consider forces of change in the world.

\section{Global Forces of Change}

There are forces of change in the global order. These forces which affect the way the world is structured and perceived include social forces, technological forces, environmental forces, economic forces, educational forces, political forces, cultural forces, natural forces, and so on. The natural forces of change, such as earthquakes, tornadoes and tsunamis, are not man-made occurrences whereas the other forces of change are most times artificial. Though we will discuss natural forces of change in this work, we will relate them more to human activities while our emphasis will be on the man-made forces because of the necessity of urging proactive efforts in the developmental agenda of Africa. As a starting point, education is the most basic force of change in the world through which all others derive their strengths. From time memorial, it has been one of the greatest forces of change. From formal, well-organised educational systems, to informal domestic/parental training, through civic education to discussion of human rights, and all forms of enlightenment, the history of the world has been changed by education. The most ardent global wars, contents of geographies of the world, uncom- 
mon technological revolutions, space explorations, and a whole lot of vast and unimaginable human escapades and exploits are offshoots of education. For instance, Aristotle was the teacher of Alexander the Great who fought most ancient wars within the last three and half centuries before Christ and is regarded as a great military warrior of all seasons. Also, at different times, men who gave attention to one form of education or the other such as Leonardo da Vinci (Vasari, 1991: pp. 284-298), Michelangelo Bounarotti (Vasari, 1991: pp. 414-488) William Shakespeare (Shakespeare, 2012: pp. 1-3; Moore, 2008: pp. 6-24), and contemporary examples like Wole Soyinka, the various Nobel Prize winners, Kwame Nkrumah, Winston Churchill, Harry Truman, Ronal Reagan, Vladimir Lenin, Margaret Thatcher, Mikhail Gorbachev, Albert Einstein, Leslie R. Groves, J. Robert Oppenheimer, Martin Luther King Jr., Nelson Mandela, Bill Gates, and Steve Jobs are world changers (Mandela. 1995: pp. 1-115; Nkrumah, 1970: pp. 78-79; Irving, 2001: p. 16, 56; Sung \& Mathisen, 2008; Bethe, 1997: pp. 175-208; Lenin, 1965: pp. 7-77; King Jr., 1963; Isaacson, 2011: pp. 57-557; Gates, 1995: pp. 1-30).

In this list, the first two made aesthetic change in the Italian community and gave the world a sense of artistic serenity while Shakespeare and Soyinka influenced the world to think in literary terms and find enjoyment through plays, prose and poetry. Incidentally, the list of Nobel Prize winners includes Mandela and Soyinka (Jeyifo, 2004: xxx). The different Nobel awardees have, at various times, promoted ideas that transform various key areas of human endeavour (Nobel Foundation, 2011). Nkrumah, Churchill, Truman, Reagan, Lenin, Thatcher and Gorbachev were strong political strategists whose decisions influenced global socio-economic and peace policies in unprecedented ways in human history while the next three, Einstein, Groves and Oppenheimer, birth ideas and projects that ended the Second World War (Einstein, 1924: pp. 1-124; Biney, 2008: pp. 129-131; Steger \& Roy, 2010: pp. 21-76; Hoover, 1987: pp. 245-268; Gorbachev, 2006: p. 134). Particularly, Einstein's idea of relativity was hijacked by Groves, Oppenheimer and the other scientists of the Manhattan Project to build the first atomic bombs thrown on Hiroshima and Nagasaki to end the war. Luther and Mandela were activists who fought racism and left indelible imprints on the minds of global nationals that racial bigotry harms the human race. The ideas of Bill Gates (1995: pp. 1-30) and Steve Jobs (Isaacson, 2011: pp. 57-557) have also transformed the way we view the computer industry. Gates thought of putting computers on every desk in the world. In the past, computers were treated as sacred elements located at certain spots of the world for the wealthy to access while other global inhabitants hero-worship them. Soon, they are on individuals' desks as playthings. As progress was made, they became toys in people's pockets, used as hand phones and browsing tablets and phablets. Part of this advancement is seen in Job's apple iphones, ipads and ipods which make all sorts of connections and personal comforts possible. The truth of the matter is that it is not only the way we do things that change, our vocabularies have also changed. Words that never existed have found their ways into our daily existence while ones that existed are becoming ambiguous or obsolete due to the way developments in the field of information technology affected the way we get educated. 
Apart from the above people, those who are viewed as changing the world negatively such as Adolf Hitler (David, 2001: pp. 16-56), Osama bin Laden (Robinson. 2001: pp. 522-530; Bruce, 2005: pp. 65-275) and Robert Stroud (Pollock, 2001: pp. 131-132; Stroud, 2016), well known as the Birdman of Alcatraz, three intelligent men who were products of education. The unfortunate aspect is that they did not allow what they knew to have positive impacts on their world. Hitler's aggressions in Europe while finding a compatible ally in Benito Mussolini occasioned the deaths of millions of people through the gas chambers and the ambitious prosecution of World War II. Though Stroud was self-educated, he made important contributions to the field of ornithology and attracted sympathy for his love for birds. However, he was reputable for the crimes concerning hate for his fellow humans, which kept him in a maximum prison for over half a century. Bin Laden's case depicts what may happen when religious education is wrongly applied. This shows that religion is also an important force of change. It may be an agent of peaceful change when well handled and cause wars and terrorism when wrongly handled. Religion probably has occasioned more wars than any known cause in history. It is capable of absorbing ideologies that can foster violent endeavours and cause national and international chaos. This is the situation with bin Laden's al-Qaeda terrorist attacks in places round the world and revolutionary activities in Bahrain, Egypt and Libya show violent activities premised on religion. In actual fact, the above cases attest to the fact that right education propels great national change and wrong education provokes personal and national decay. Little wonder that the United Nations wants nations of the world to devote much of their national budget to offer good education to their people. By this, education will contribute to social change.

The social forces of change incorporate the internet and the field of information media which are products of information technology (Cochrane \& Pain, 2000: pp. 6-10). In this sense, this development is part of the technological forces. In more recent times, the social media as twitter and facebook facilitate social rapport, making possible unimaginable extents of human interaction, such that the world is no longer seen as a community but as a household. In this sense, the idea of global community seems to be disappearing for that of global household as people get so intimate and share both private and public information with a snap of finger through pocket phones. Obviously, the field of information technology has influenced the globalisation process, which is an integration of almost all aspects of human life and day to day activities. As at now, globalisation has changed the way information is disseminated in the world (Mackay, 2000: pp. 76-79). Apart from social interconnectedness, the rate of proliferation and circulation of information surpasses what man ever knows in several hundreds of years. The most unusual thing is that information is easy to transfer. Coded aspects of knowledge can be viewed without complex systems of transfer and it becomes easy for trade groups and corporations to gain from their investments by a click of the mouse and without face to face interaction with their customers. As the internet is popular in quick spreading of information, so also information is sent via satellite cable networks to our televisions from one end of the world to the other. By and by, the world is trans- 
formed by the field of information technology. As at present, the interface between the internet and television is being smoothened so that both can be viewed as a unit and means of information circulation without any real distinction. Putting these events in view, sailing on the wings of information technology, globalisation produces cultural, social, economic, psychological, political, and so on, changes in global affairs and human interaction.

As at today, globalisation cum information technology constitutes an essential force of change in the world (Sklair, 1999: p. 152; Ogunbanjo, 2001: pp. 76-77). From the ruling elites to the beggar on the street, it affects everyone everywhere in the world. In terms of socio-cultural changes, globalisation has both positive and negative impacts on the inhabitants of the world. In considering cultural globalisation, one of the positive impacts it has is the interlacing of culture that allows different cultures the opportunity of learning from one another and imbibing useful things in the different cultures. Thus, it occasions the spreading of universal values, such as democracy, freedom, and human rights. It is much easy for different peoples in the world to react violently against injustices. Instances are the 2011 wave of revolutionary activities spreading across the Arab world and the Occupy Wall Street protests that started in a little corner of New York and spread to nations of the world (Heydemann, 2013: pp. 69-73). These two cases are reactions against activities of elitist rulers and the privileged class (Gitlin, 2012: pp. 6-18). The latter is against the passive stand of American Government to do something about the inequality status of the rich and the poor. The rich, forming only one percent, have the economic situation favouring their amassing more wealth while the poor continue to lose out. The former is against the oppressive rule of rulers who perpetuate themselves in power despite that they are no longer ruling in manners that are to the people's advantage. These rulers, apathetic to the concerns of their peoples, fostered socio-political and economic systems that promoted a culture of violence, indecency and all sorts of corrupt practices. An unfortunate aspect of the information technology in relation to these events is that youths are the most negatively affected. As they follow the events and view some of the protagonists as heroes, it becomes easy for youths across nations to learn acts of terrorism and intense violence. This largely contributes to terrorist activities in many places like Nigeria and Pakistan. Apart from this, the satellite or the internet has led to perpetration of dastardly activities or social vices as scam, pornography, and so on, that pose a lot of psychological trauma to global inhabitants because of tendencies for rape, assaults, armed robbery, and other forms of domestic and public violence and injustices. Thus, untold corrupt practices spread across all spheres of our societies. Considering the above, globalisation can be seen as affecting the world politically, socially, politically and psychologically (Kellner, 1998: p. 26). As much as globalisation affects the different areas of our world, it obviously has great impacts on the global economy in general and the African economy in particular.

What also constitute forces of change are the environmental factors. These are part of the great challenges the world is combating. These show in several ways: from the oil spillages that result from activities of oil producing companies to the impact of chlo- 
rofluorocarbons (CFCs) that leaked and depleted the earth's ozone layer to the acid rain that pollute the environment. Environmental factors can cause natural disasters. For instance, the depletion of the ozone layer allows ultraviolent rays to the earth and increases the intensity of the impact of the sun on the earth (Gilberto, Gutman, \& Maletta, 1989: p. 376). The result has been that the ices concentrated at the global poles are melting. Thus, the water levels of the seas increase to cause natural disasters for those around the sea coasts. In some cases, livestock and farm produces have been lost to acid rains. Environmental factors may be controlled, if not natural disasters as cyclone, hurricane, etc., most especially if they deal with CFCs. As at now, the world is fighting hard to combat environmental forces of change so as to make the earth inhabitable and enjoyable for humans (Miller, 1991: pp. 609-612).

There are also political forces of change. In talking about this, democracy is the most pronounced. Democracy is taken to be the ideal government that all nations of the world strive to attain (Dryzek, 2006: pp. 148-150). The common orientation the world has and which is more of a household concept for the lay man is Abraham Lincoln's, perhaps most quoted, phrase that it is "the government of the people by the people for the people." (Nicolay \& Hay, 1905: p. XXVIII). It understates the fact to affirm that democratic policies affect the way most of the world's nations are governed. In well-organised societies, policies formulated based on democratic ideals sweep across different aspects of life. The change imposed by democracy as a force of change is now America driven. America is the main advocate of modern democracy that is converting the rest of the world through democratic principles. The world is not just embracing it but buying into it hook, line and sinker while each nation attempts to domesticate it for her national relevance. Thus, in instances when the governments in these nations are seen to be astray, the people put pressures to force them to repeal all wrong policies or change from their pursuit of wrong actions. It is now generally believed that following democratic ideals enables a nation to minimise the risks of bad leadership to which autocratic and dictatorial regimes are subject. Political forces lead to institutional reforms which can lead to greater benefits for the people in a nation. In situations where institutions are allowed to retain unproductive structures the possibilities of having a dysfunctional state exist. The paradox of the issues with political forces, like all other forces of change, is that they bring institutional transformation if allowed to yield productive results and may equally produce evil results when non-virile leadership structures are entertained.

All the above affect economic forces of change that in turn affect the inhabitants of the world. Economic determinants control what happens to people in the world. Activities of aggrieved trade unions can paralyse a national economy, leading to loss of millions of dollars. Also, a little economic recession, loss of jobs, etc, can cause untold hardship in any nation of the world. The recent state of global economic depression leaves the world struggling to cope with extreme poverty, whereas, the rich is getting richer in the world. For instance, the makers of the social media are silent billionaires. The reality of the modern economy is its global integration that causes ripple effects in the world, leaving huge impacts on Africa. Obviously, one way or the other, all the 
above mentioned forces contribute to Africa's extensive poverty.

\section{Addressing Poverty Holistically in Africa}

Putting the negative implications of the above factors on Africa into consideration, it is germane for us as Africans to tackle poverty in a holistic sense so as to solve our problems and attain higher levels of development like other power blocks of the world. Usually, our major problem is lack of focus on the right approaches to solving our problems. We have not also developed the means of overcoming the things we identified as aspects of poverty. The continent is loaded with vast resources for huge economic success that can enable her to be an economic superpower of the world. Unfortunately, she has failed to realise this and, thereby, keep herself underdeveloped. Quite a number of times, people quote giant revolutionary writers like Walter Rodney (especially his work entitled How Europe Underdeveloped Africa) (Rodney, 1972: pp. 103-222) and Frantz Fanon (1967: pp. 1-191) who wrote in reaction to colonial domination while lamenting colonial conquest. To quote these people is not as important as identifying our problems and solving them. To curb the problem of underdevelopment, we need to ask ourselves, "How has Africa underdeveloped herself?" It is undisputable that we have access to great intellectual resources now than in the time of the slave trade and have been unable to translate them to help ourselves long after western imperial rule. We must make a clean departure from the past we cannot change, even though we can learn from it, to a future that is ahead of us and our children. Pan-africanism becomes baseless unless we articulate ideas that take a holistic perspective to tackling poverty and addressing issues appropriately so that the continent can make lasting gains. We need to transform intellectually if we will transform morally. Overcoming intellectual poverty helps us to make right rational choices to live morally satisfying lives that can help the overall development of our continent.

It should also be noted that moral failure is not dependent on any nationality. It is usually a universal failure of man. For instance, moral degenerates are in the developed world as well as the less developed. The early Pan-africanists who showed traits or possibilities of helping the continent to transcend poverty soon degenerated to the extent of reducing the continent to a horrible state of economic poverty because of their moral poverty. One of the problems that hinder us from attaining a meaningful development while foreigners who come to the continent gain from our systems at our expense is the fact that we shift blames rather than address our moral problems. As we observed in the last paragraph, one of the areas of blame-shifting is the consideration that colonialism is the cause of our developmental problems. This occasions Rodney's (1972: pp. 103222) and Fanon's (1983: pp. 1-118; 1986: pp. 17-27) debunking of European loots of Africa. Obviously, colonialism and other factors have been instrumental in making us arrive at the present status of ignominy. However, an equally germane question is this: Why should Africa fail to embark on self-actualisation and self-transformation instead of crying over spilt milk? Our records after freedom from colonialism are worst. Moral corruption has denigrated us more in the post-independence era than anything. This 
has been decried by many writers of African descent and several others outside the continent. According to the Frontline Fellowship (2016):

The corruption and abuse of the relief aid in Ethiopia was the ultimate scandal: $100 \%$ import tax was charged on all free relief aid! Brand new Mercedes Benz trucks were required with $100 \%$ import tax imposed on all these trucks for transporting the food. All these trucks had to be signed over to the marxist government of Ethiopia! (And all this while US\$70 million was spent on the "Anniversary of the Revolution" celebrations in 1984-1/2 for alcohol!). In fact, much of the relief aid and food was used for the many Cuban, Soviet and East German military who were involved in causing the famine. Some of the food was actually exported in payment for weapons!... In South Africa...I have seen professional beggars at work. I have seen "cripples" letting down their strapped leg and stretching and walking unaided without their crutches; and I've seen the "blind" lift up their dark glasses to count the money in their hat. Some street children have told me that they can make an average of R200 a day from begging! In all too many cases our casual and spontaneous handing over of some coins to strangers begging on the streets does more harm than good. Giving to beggars on the streets often goes to subsidising drunkenness, smoking, drugs, prostitution and gambling. Some of the beggars are child prostitutes and thieves using begging as a cover while looking for opportunities.

In actual fact, a mindset for cheating cannot enhance our growth and development. Though we achieved political freedom from colonial dictatorship, we became captive to moral poverty. Thus, we develop an egregiously irresponsive moral conscience that has plagued the continent for decades since the independence of the nations (Dabashi, 2012: pp. 8-25). By moral conscience we mean the human sense of reasoning or instinct to morally judge an action to be right or wrong. It takes a moral conscience to stir a people to act morally and satisfy others that are their neighbours (Òkè, 1988: pp. 79-103). It is the root of the exercise of the moral will. A person deficient in the exercise of the moral will accepts anything as a standard and ends up compromising important principles (Solomon \& Green, 1999). This is where we have been failing as corruption eats deep into the fabrics of our nations and economic poverty plagues us. Thus we become objects of ridicule in the comity of nations. In Africa, we are not deficient of the ideas concerning how to overcome moral poverty, as these show in the African worldviews. However, our main failure lies in not appropriating the ideas for growth and development.

In Africa, though many people claim to undergo the purification of their souls by consciousness or self-awareness that they ponder certain basic truth that can help overcome different types of poverty, many only pay lips service and use the idea of spirituality as cover up for injustice. This is a major problem among political office holders in a place like Nigeria. As noted earlier, Osigwe holds that truth is pivotal to human consciousness of the laws governing the events of the universe. African societies can be completely transformed if their inhabitants can come to self-awareness and 
transcend the negative impacts of earlier mentioned forces of change. This is when concepts like hard work, diligence, other-regarding, national development, national conscience, virtuous life, good living, selflessness, fellow feeling, patriotism, etc, will become more meaningful to the people (Esheté, 1982: pp. 500-501). Those who have not come to self-awareness and never know why they are in their nations, what to aspire for, the roles they are to play in the society, etc, may never contribute to national development in any form. There have been much moral poverty and economic poverty situations in Africa because we refuse to do the necessary spiritual exercise of soulsearching and pondering on the truth that can help us appreciate our existence as a people and attain some levels of moral consciousness.

We often fail to realise that moral consciousness is essential for developing viable social relations and promoting enduring development. Great development may be undermined when moral consciousness is undermined because moral consciousness enhances social relations by promoting respect for others. There are numerous cases in history of leaders who break down social relations between them and their people. The list includes Hitler and a host of others from Africa. Two recent cases are those of Côte d'Ivoire's Lauren Gbagbo and Muhammad Gadhafi. Gbagbo lost his nation's 2011 election as the incumbent President but decided to hold tenaciously to power. As reported by Josephine Whitaker (2011), he employed state machineries to deal will Alasan Quattara, his opponent who won the election. This also resulted in guerrilla warfare and an eventual overthrow of Gbagbo's government. Apart from this, the situation partitioned the country to two and created a tense atmosphere of proliferation of small arms that may heighten brigandage against the people. If Gbagbo had not taken for granted that opposition parties are important in national development and progressive socio-economic and political advancement, he would not have exposed his country to such hazard. As another worst case scenario of the African situation of social poverty, the Libyan dictator, Muhammad Gadhafi, plunged his country into civil war because he did not value the people and they ousted him at all cost (Pradhad, 2012: p. 8; Andersson \& Abdelkader, 2013: p. 36, 44). What he cost his nation is much. Unfortunately, he opened the economy of his country to great risks by allowing the savage barrage and infusion of unreasonable ideas capable of depressing the nation's economy and make those who are interested in the nation's oil to come scamping for it to the detriment of the economy. As at now, the nation's central government is so weak with criminals dominating her periphery. What Gadhafi caused is an emotional instability in the people that will haunt them for a long time. Apart from this, many of the people may never regain their means of livelihood. This may also have grave consequences for the trainings and development of their children. Their welfare may be at the nation's expense to the disfavor of the economy (Amin, 2012: viii). Homes that are split by Gadhafi's drafting of some of their members into his army to war against their people may take some time to heal up. On the overall, the national instability that results from the war may, for a long time to come, take its toll on the nation's economy, as it will take an enormous amount of his country's hard-earned petrodollars to rebuild the nation. 
In actual fact, social poverty promotes dictatorship and debases human dignity. Possibilities of beneficial economic, human and national developments are diminished where people value themselves less. In most serious democratic nations, part of the considerations for voting any candidate to power is the social relations they have with the people. It is observable that candidates seeking elections usually come down to the people and give the impressions that they are interested in relating well with them, their causes and concerns. This is one of the things that usually cause the people to hurt and feel betrayed when the people for who they vote eventually fail to perform (Human Rights Watch, 2007: pp. 2-3). In the case involving Africa, most of the time, we pay lips service. Nigeria is a typical case of this kind of situation. For instance, the nation has many people in the political class who court electorates during campaigns for elections and, eventually, never lived up to expectation. As such, there are leaders who give little attention to the people's worth so far they are benefiting from the proceeds of governance. The whole idea of social relations should be well-meaning interactions that respect the other person, his views, trust in us, his values, and so on. This is one of the areas where we fail in Africa and put our economy in jeopardy. For the continent to make considerable and enviable progress among nations, it must equally take care of the flaws in her social dealings.

\section{Conclusion}

So far, this paper discussed various types of poverty, their causes and how African nations can profit from overcoming their present predicaments of poverty. It equally discussed forces of change in the world considering how these affect the world and, by implication, Africa as well as other nations. It maintains that, up till now, Africa has mainly concentrated on economic poverty, which is just an aspect of poverty, as what depicts and accounts for its state of poverty. Observing this as a serious deficiency in Africans' conceptualisation of poverty, it shed light on the issues involved in the description of other various types of poverty. It argued that utmost attention should be given to addressing all these forms of poverty that are really responsible for the continent's lingering state of economic poverty. This is necessary so as to fully combat the continent's situation of economic poverty and achieve development and sustenance. So as not to jeopardise her overall economic and material interests and success in the comity of nations, Africa needs to take seriously the task of tackling poverty and pursue this holistically. This is when the vast human and material resources at her disposal can actually profit her immensely.

\section{References}

Abraham, W. E. (1962). The Mind of Africa. Chicago, IL: Chicago University Press.

Adesina, J. O. (1994). Unions, Workers \& the Development Process: Controversy, Dilemmas and New Openings. In U. Himmelstrand, K. Kinyanjui, \& E. Mburugu (Eds.), African Perspectives on Development (pp. 183-185). London: James Currey Ltd.

Amin, M. (2012). After The Spring: Economic Transitions in the Arab World. London: Oxford University Press. 
Andersson, T., \& Djeflat, A. (Eds.) (2013). In The Changing Landscape of the Middle East. In T. Andersson, \& A. Djeflat (Eds.), The Real Issues of the Middle East and the Arab Spring: Addressing Research, Innovation and Entrepreneurship (pp. 19-57). New York: Springer.

Anyiam-Osigwe, C. et al. (Eds.) (2004). Introspectionism: Green Grasses of Home: The Key to Development Is within and around You. Brief on the Central Theme of the Sixth Session, Emmanuel Onyechere Osigwe Anyiam-Osigwe Lecture Series (pp. 33-38). Nigeria: Osigwe Anyiam-Osigwe Foundation.

Appiah, K. A. (1992). My Father's House: Africa in the Philosophy of Culture. Oxford: Oxford University Press.

Appiah, K. A. (2003). Thinking It through: An Introduction to Contemporary Philosophy. Oxford: Oxford University Press.

Appiah, K. A. et al. (2005). Ethics in a World of Strangers: W.E.B. Du Bois and the Spirit of Cosmopolitanism. In Justice, Governance, Cosmopolitanism, and the Politics of Difference Reconfigurations in a Transnational World (pp. 26-30). Distinguished W.E.B. Du Bois Lectures, Berlin: Forschungsabteilung der Humboldt-Universität zu Berlin.

Aristotle (2004). Nichomachean Ethics (Book II. Roger Crisp. Trans. and Ed.). Cambridge: Cambridge University Press.

Beitz, C. R. (2005). Cosmopolitanism and Global Justice. The Journal of Ethics, 9, 11-27.

Bethe, H. A. (1997). J. Robert Oppenheimer. April 22, 1904-February 18, 1967. Washington DC: National Academies Press.

Bigman, D. (2011). Poverty, Hunger, and Democracy in Africa: Potential and Limitations of Democracy in Cementing Multiethnic Societies. New York: Palgrave Macmillan. http://dx.doi.org/10.1057/9780230248489

Biney, A. (2008). The Legacy of Kwame Nkrumah in Retrospect. The Journal of Pan African Studies, 2, 129-131.

Bodunrin, P. (1981). The Question of African Philosophy. Philosophy, 56, 161-179. http://dx.doi.org/10.1017/S0031819100050014

Bruce, L. (Ed.) (2005). Messages to the World: The Statements of Osama bin Laden (James Howarth Trans.). London and New York: Verso Books.

Cochrane, A., \& Pain, K. (2000). A Globalizing Society? In D. Held (Ed.), A Globalizing World? Culture, Economic, Politics. London and New York: Routledge.

Coetzee, P. H., \& Roux, P. J. (Eds.) (1998a). Readings in African Philosophy. London and New York: Routledge.

Coetzee, P. H., \& Roux, P. J. (Eds.) (1998b). The African Philosophy Reader. Second Edition: A Text with Readings. London and New York: Routledge.

Dabashi, H. (2012). The Arab Spring: The End of Colonialism. London and New York: Zed Books.

de Soysa, I. (2001). Paradise Is a Bazaar? Greed, Creed, Grievance and Governance. UNUWIDER, Discussion Paper 2001/42. 1-5.

Dixon, A. (2010). Famous Racists in History: John Locke. www.innercivilization.com/2010/03/famous-racists-in-history-john-locke.html? $\mathrm{m}=1$

Dower, N. (1998). Human Rights, Global Ethics and Globalization. In R. Axtmann (Ed.), Globalization and Europe: Theoretical and Empirical Investigations (pp. 109-115). London: Pinters.

Dryzek, J. S. (2006). Deliberative Global Politics: Discourse and Democracy in a Divided World. UK: Polity Press.

Einstein, A. (1924). Relativity: The Special and General Theory (Robert W. Lawson Trans.). 
London: Methuen \& Co. Ltd.

Enyimba, M. (2005). Racism and Philosophy. In J. M. Elogbo et al. (Eds.), Racism, Philosophy and African Thought. Ibuanyidanda Philosophy or Complementary Reflection: African Philosophy and General Issues in Philosophy. http://www.frasouzu.com/

Esheté, A. (1982). Character, Virtue and Freedom. Philosophy, 57, 495-513. http://dx.doi.org/10.1017/s0031819100056126

Eze, E. C. (1997). The Color of Reason: The Idea of "Race” in Kant's Anthropology. In E. C. Eze (Ed.), Postcolonial African Philosophy: A. Critical Reader. USA: Blackwell Publishers.

Fanon, F. (1967). Toward the African Revolution. New York: Grove Press.

Fanon, F. (1983). The Wretched of the Earth. London: Penguin.

Fanon, F. (1986). Black Skin White Masks. UK: Pluto Press.

Frontline Fellowship (2016). Poverty-Its Causes and Cure. http://frontline.org.za/index.php?option=com_content\&id=966:poverty-its-causes-andcure

Gates, B. (1995). The Road Ahead. USA: Penguin Readers.

Gilberto, G., Gutman, P., \& Maletta, H. (1989). Global Impoverishment, Sustainable Development and the Environment: A Conceptual Approach. International Social Science Journal, 41, 375-397.

Gitlin, T. (2012). Occupy Nation: The Roots, the Spirit, and the Promise of Occupy Wallstreet. New York: IT Books.

Gorbachev, M. (2006). The Roads We Travelled, the Challenges We Faced. Moscow: Izdatelstvo VES MIR (IVM) (for the Gorbachev Foundation).

Gyekye, K. (1997). Tradition and Modernity: Philosophical Reflections on the African Experience. New York and Oxford: Oxford University Press. http://dx.doi.org/10.1093/acprof:oso/9780195112252.001.0001

Halvorson, R. T. (2003). Poverty and Property: Global Justice and Property Rights. An unpublished Long Essay submitted to the Department of Philosophy and Government, Cambridge: Massachusetts.

Hegel, G. W. F. (1956). The Philosophy of History. New York: Dover.

Hensbroek, P. B. (1998). African Political Philosophy, 1860-1995: An Inquiry into Families of Discourse. The Netherlands: Universiteitsdrukkerij, Groningen in cooperation with Centre for Development Studies, University of Groningen.

Heydemann, S. (2013). Tracking the "Arab Spring": Syria and the Future of Authoritarianism. Journal of Democracy, 24, 59-73. http://dx.doi.org/10.1353/jod.2013.0067

Himmelstrand, U. (1994). Perspectives, Controversies \& Dilemmas in the Study of African. In U. Himmelstrand, K. Kinyanjui, \& E. Mburugu (Eds.), African Perspectives on Development: Controversies, Dilemmas \& Openings (pp. 16-35). London: James Currey Ltd.

Hoover, K. R. (1987). The Rise of Conservative Capitalism: Ideological Tensions within the Reagan and Thatcher Governments. Comparative Studies in Society and History, 29, 245-268. http://dx.doi.org/10.1017/S0010417500014493

Hountondji, P. (1983). African Philosophy: Myth and Reality. Bloomington, IN: Indiana University Press.

Human Rights Watch (2007). Criminal Politics, Violence, “Godfathers" and Corruption in Nigeria. In Human Rights Watch $A$ (Vol. 19, No. 16, pp. 1-122). New York: Human Rights Watch.

Hume, D. (1826). An Enquiry Concerning Human Understanding. The Philosophical Works of 
David Hume, IV. London: Adam Black and William Tait.

Irele, A. (1986). Contemporary Thought in French Speaking Africa. In I. J. Mowoe, \& R. Bjornson (Eds.), Africa and the West: The Legacies of Empire. New York: Greenwood Press.

Irele, D. (1993). In the Tracks of African Predicament: Philosophy and Contemporary SocioEconomic Political Problems in Africa. Ibadan: Option Book and Information Services.

Irving, D. (2001). The Secret Diaries of Hitler's Doctor. UK: Parforce Ltd.

Isaacson, W. (2011). Steve Jobs. New York and London: Simon \& Schuster.

Jeyifo, B. (2004). Wole Soyinka: Politics, Poetics and Postcolonialism. Cambridge: Cambridge University Press.

Kagabo, L. (2004). Alexis Kagame (1912-1981): Life and Thought. In K. Wiredu (Ed.), A Companion to African Philosophy. USA: Blackwell.

Kant, I. (1997). On the Different Races of Man. In E. C. Eze (Ed.), Race and the Enlightenment: $A$ Reader. USA: Blackwell Publishers.

Kellner, D. (1998). Globalization and the Postmodern Turn. In R. Axtmann (Ed.), Globalization and Europe: Theoretical and Empirical Investigations. London: Pinters.

King Jr., M. L. (1963). Letter from Birmingham Jail. Microsoft Encarta Microsoft Corporation.

Lenin, V. I. (1965). On Religion. Moscow: Progress Publishers.

Mackay, H. (2000). The Globalization of Culture? In D. Held (Ed.), A Globalizing World? Culture, Economic, Politics. London and New York: Routledge.

Mandela, N. (1995). Long Walk To Freedom. Boston, MA: New York: Little, Brown and Company.

Marx, K. (1956). Theses on Feuerbach. In T. B. Bottomore, \& M. Rubel (Eds.), Karl Marx: Selected Writings in Sociology and Social Philosophy. London: C. A. Watts.

Miller, R. B. (1991). Social Science and the Challenges of Global Change. International Social Science Journal, XLIII, 609-615.

Minot, N. et al. (2010). Trade Liberalization and Poverty in the Middle East and North Africa. USA: International Food Policy Research Institute.

Momoh, C. S. (1981). Modern Theories in an African Philosophy. Nigerian Journal of Philosophy, 1, 8-22.

Moore, J. (2008). William Shakespeare: An Overview of His Life, Times, and Work. Canada: The National Arts Centre English Theatre Programmes for Student Audiences.

Mudimbe, V. Y. (1986). On the Question of an African Philosophy: The Case of French Speaking Africa. In I. J. Mowoe, \& R. Bjornson (Eds.), Africa and the West: The Legacies of Empire. New York: Greenwood Press.

Mudimbe, V. Y. (1998). The Invention of Africa: Gnosis, Philosophy, and the Order of Knowledge. Bloomington and Indianapolis, IN: Indiana University Press.

Nicolay, J. G., \& Hay, J. (Eds.) (1905). The Complete Works of Abraham Lincoln. IX. New York: Tany-Thomas Co.

Nkrumah, K. (1970). Consciencism: Philosophy and Ideology for De-Colonization. USA.

Nobel Foundation (2011). www.Nobelprize.org

Nozick, R. (1974). Anarchy, State and Utopia. New York: Basic Books.

Ó'Tuathai, G., Herod, A., \& Roberts, S. M. (1998). Negotiating Unruly Problematics. In G. Ó'Tuathai, \& S. M. Roberts (Eds.), An Unruly World? Globalization, Governance, and Geography(10-20). London: Routledge. 
Oguejiofor, J. O. (2002). Kwasi Wiredu and the Possibility of a History of African Philosophy. In O. Oladipo (Ed.), Thirdway in African Philosophy: Essays in Honour of Kwasi Wiredu. Ibadan: Hope Publications.

Ogunbanjo, B. (2001). Globalization and African Dilemma. Humanities Review, 1, 74-80.

Òkè, M. (1988). Self-Interest as the Ground of Moral Obligation. Second Order, 1, 79-103.

Oladipo, O. (2009). Holistic Approach to Existence and Development. In O. Oladipo, \& A. B. Ekanola (Eds.), The Development Philosophy of Emmanuel Onyechere Anyiam Osigwe Anyiam. Ibadan: Hope Publications.

Omeje, K. (2006). Petrobusiness and Security Threats in the Niger Delta, Nigeria. Current Sociology, 54, 477-499. http://dx.doi.org/10.1177/0011392106063915

Oruka, O. H. (Ed.) (1990). Sage Philosophy: Indigenous Thinkers and the Modern Debate on African Philosophy. Leiden: E. J. Brill.

Pogge, T. (Ed.) (2007). Freedom from Poverty as a Human Right: Who Owes What to the Very Poor? Oxford: Oxford University Press.

Pollock, G. C. (2001). The Birdman of Alcatraz. Journal of Avian Medicine and Surgery, 15, 131-132. http://dx.doi.org/10.1647/1082-6742(2001)015[0131:TBOA]2.0.CO;2

Pradhad, V. (2012). Arab Spring, Libyan Winter. Oakland, CA: AK Press Publishing.

Rawls, J. (1999). Law of Peoples. Cambridge, MA: Harvard University Press.

Richardson, T. (2011). John Locke and the Myth of Race in America: Demythologizing the Paradoxes of the Enlightenment as Visited in the Present. Philosophical Studies in Education, 42, 101.

Robinson, A. (2001). Bin Laden: Behind the Mask of the Terrorist. New York: Arcade Publishing.

Rodney, W. (1972). How Europe Underdeveloped Africa. London: Bogle-1'Ouverture Publications.

Rojas, M. (2014). Well-Being and the Complexity of Poverty: A Subjective Well-Being Approach. http://www.researchgate.net/publication/23780597_well-being_and_the_complexity_of_povert Y_A_Subjective_Well-being_Approach

Russell, B. (1945). A History of Western Philosophy. New York: Simon and Schuster.

Saliu, H. A., Luqman, S., \& Arazeem, A. A. (2007). Environmental Degradation, Rising Poverty and Conflict: Towards an Explanation of the Niger-Delta Crisis. Journal of Sustainable Development in Africa, 9, 275-296.

Shakespeare, W. (2012). Biography.com. http://www.biography.com/people/william-shakespeare-9480323

Singer, P. (1986). Famine, Affluence and Morality. In J. Perry, \& M. Bratman (Eds.), Introduction to Philosophy: Classical and Contemporary Readings (pp. 573-580). London: Oxford University Press.

Singer, P. (2002). One World: The Ethics of Globalization. New Haven and London: Yale University Press.

Sklair, L. (1999). Competing Conceptions of Globalization. Journal of World Systems Research, $5,143-163$.

Solomon, R., \& Green, J. K. (1999). Morality and the Good Life: An Introduction to Ethics through Classical and Contemporary Sources. USA: McGraw-Hill.

Steger, M. B., \& Roy, R. K. (2010). Neoliberalism: A Very Short Introduction. Oxford: Oxford University Press. http://dx.doi.org/10.1093/actrade/9780199560516.001.0001

Stiglitz, J. (2002). Globalization and Its Discontents. USA: Penguin. 
Stiglitz, J. E. (1996). Some Lessons from the East Asian Miracle. The World Bank Research Observer, 11, 151-177. http://dx.doi.org/10.1093/wbro/11.2.151

Stiglitz, J. E. (2007). Multinational Corporations: Balancing Rights and Responsibilities. Proceedings of the Annual Meeting (American Society of International Law), 101, 3-60.

Stiglitz, J., \& Charlton, A. (2005). A. Fair Trade for All: How Trade Can Promote Development. Oxford: Oxford University Press.

Stroud, R. (2016). The Birdman of Alcatraz. Alcatraz History: Where the Voices of Alcatraz Come to Life. www.alcatrazhistory.com/stroud.htm

Sung, C. H., \& Mathisen, D. (2008). J. Robert Oppenheimer Papers: A Finding Aid to the Collection in the Library of Congress (Michael Spangler and Stephen Urgola Revised and Expanded). Washington DC: Manuscript Division, Library of Congress.

The World Bank (1990). World Development Report 1990-Poverty: World Development Indicators. London: Oxford University Press. http://dx.doi.org/10.1596/0-1952-0851-X

Thomas, C. (2001). Poverty, Development and Hunger. In J. Baylis, \& S. Smith (Eds.), The Globalization of World Politics: An Introduction to International Relations (2nd ed.). Oxford: Oxford University Press.

UNEP (1992). The World Environment 1972-1992 (Mostafa et al. Eds.). London: Chapman and Hall.

Vasari, G. (1991). The Lives of the Artists (Julia Conaway Bondanella and Peter Bondanella Trans.). Oxford: Oxford University Press.

Velasquez, M. (1999). Philosophy: A Text with Readings (7th ed.). USA: Wadsworth.

Watts, M. (2004). Human Rights, "Violence and the Oil Complex, Niger Delta Economies of Violence. "Working Paper 2, Institute of International Studies, Berkeley, CA: University of California.

Whitaker, J. (2011). Quattara Calls for West African Intervention Force to Remove Gbagbo. Open Security. http://www.opendemocracy.net/opensecurity/security_briefings/060111

Wight, M. (1966). Why Is There No International Theory? Diplomatic Investigations: Essays in the Theory of International Politics (Herbert Butterfield and Martin Wight Eds.). London: George Allen and Unwin.

Wiredu, K. (1998). The Moral Foundation of an African Culture. In P. H. Coetzee, \& P. J. Roux (Eds.), Readings in African Philosophy. London and New York: Routledge. 
Submit or recommend next manuscript to SCIRP and we will provide best service for you:

Accepting pre-submission inquiries through Email, Facebook, LinkedIn, Twitter, etc. A wide selection of journals (inclusive of 9 subjects, more than 200 journals)

Providing 24-hour high-quality service

User-friendly online submission system

Fair and swift peer-review system

Efficient typesetting and proofreading procedure

Display of the result of downloads and visits, as well as the number of cited articles

Maximum dissemination of your research work

Submit your manuscript at: http://papersubmission.scirp.org/

Or contact ojpp@scirp.org 